\title{
INTRODUCTION TO THE TINPERGEN CENTENNIAL ISSUE
}

On April 12,2003 it was hundred years ago that Jan Tinbergen was bon. In 1969 he received, rogether with Ragnar Frisch, the frrst Nobel Prize in Economics 'for having developed and applied dynamic models for the analysis of economic processes'. In this issue of De Economist, which commemorates Tinbergen's $100^{\text {th }}$ anniversary, three other Nobel laureates, viz. Paul Samuelson, Lawrence Klein and Robert Solow, give their views on this and other contributions by Thimergen to economic seience. In addition this issue contains six articles giving present-day views on topics which were high on Tinbergen's research agenda, as well as an overview of articles Tinbergen wrote for De Economist.

Jan Tinbergen started his academic career as a theoretical physicist. But, still as a sudent in Leiden, appalled by the conditions of poverty in which the local population lived and wishing to contribute to the combat against such social evils, he decided to become an economist after having obtained his doctorate in mathematics and physics. This decision was characteristic of Tinbergen and his attitude towards science. The hundreds of articles he wrote and the path breaking contributions he made to economic science were always inspired by the social problems he observed. For example, during the great depression of the $1930 \mathrm{~s}$, he worked on the modelling of business cycles and, together with others, laid the foundation for econometrics. Other examples are his pioneering work in economic policy analysis and development plaming. In other words, his approach to economics always had a purpose and his contributions to sconomics related directly to his ideals. The brief survey of Tinbergen's professional life presented below gives further testimony of this attitude.

During his long life Tinbergen infuenced and inspired many people. To his students he was the famous man who nevertheless approached them as equals and who, in class, offered remarkably lucid insights. His colleagues were often taken by surprise when he pointed at promising areas of research or new applications they had been overooking already for some time. And others admired him for his compassion with the poor, his unrelenting commitment to a better world and his active participation in social movements.

It is only appropriate that De Economist devote a commemorative issue on the occasion of Tinbergen's $100^{\text {th }}$ anniversary, having profted from his work as a member of the editorial board from 1946 to 1987 and baving published nearly forty of his articles in De Economist. Most of these articles related directy to the areas of research to which Tinbergen made original contributions. In an article written for this occasion, Jacob Kol surveys most of the articles Tinbergen wrote for De Economist as well as the reactions they elicited from other researchers.

This Special Issue commences with brief statements by Paul A. Samuelson, Lawrence R. Klein and Robert M. Solow, three Nobel laureates who knew Tin-

De Economist $152,161-165,2004$ 
bergen well. They relate to his idealism, his scientific contributions and the way the latter affected their work, and to the progress economic science has made since then.

The other articles are all closely connected with Tinbergen's work, presenting present-day views on various economic, technical/methodological and policy problems that Tinbergen aimed to tackle. They cover four fields; econometrics for policy; business-cycle analysis; labour market and income distribution; globalization, growth and poverty.

Chris Sims assesses progress and regress in econometric modelling techiques since 1939, the yeat in which the famous controversy between Keynes and Tinbergen uncovered a number of problems that econometric modellers have to face. Sims recalls impotant steps forward on the problems related to expectations, simultaneity and probability, but notes that current model building practice appears to jgnore the solutions that have been found. He discusses various reasons for this regress and points to Bayesian thinking as the way out, quoting Tinbergen in suppont of this perspective. From recent work on Markov Chain Monte Carlo methods in econometrics and on the relation of econometric modelling and model choice to policy analysis, Sims derives new signs of progress.

The use of econometric models for policy analysis is the theme taken up by Henk Don, the sixth successor to Tinbergen as Director of the Dutch Central Planning Bureau, nowadays referred to as CPB Netherlands Bureau for Economic Policy Analysis. Don reconsiders the problems Frisch and Tinbergen foresaw for the use of policy models and discusses the relevance of the solutions they proposed. Frisch worried specifically about the reliability of an econometric model for finding the best possible policy, because many equations might be susceptible to change under different policies. Tinbergen was mostly concerned about the specification of the welfare function. While the problems they formulated are still with us, Don argues that the solutions they offered are not very helpful. He explains how both problems are handled in current practice at CPB and states two priorities for improvement.

Iim Stock investigates the current state of knowledge about structural stability of macroeconomic relations and its implications for forecasting. In Tinbergen's models, business cycles are the ontcome of shocks or impulses that propagate through the economy in a complicated, possibly cyclical, dynamic pattern. However, before World War II the data sets were small and inference depended to a large extent on expert judgement. Now econometricians have much larger data sets and also a larger set of models and statistical instruments to analyse the stability of macroeconomic relations. Stock finds substantial evidence of instability in stuctural relations and then moves to the question whether reliable forecasts can be produced when the underlying model is unstable. Stock conchdes that recent work on new time series methods and models can prove useful, in particular when the data sets are large. Also, the new generation of stuctural, dynamic stochastic equilibrium models may be helpful in this context. But achiev- 
ing Tinbergen's vision of a stable quantitative stuctural macroeconomic model for policy design renains a formidale challenge.

Herman van Dijk's contribution to this volume also falls within the business cycle theme. Using annual data on real per capita Gross Domestic Product (GDP) of seventeen industrialized nations for the twentieth century, Van Dijk discusses the relative importance of shocks versus cycles. As an extension of the class of vector autoregressive models, a class of flexible neural network models is specified in order to capture the long nun national patterns of the development in real GDP per capita. Van Bijk finds nonlinear positive trends in the levels of real GDP per capita and uncovers shocks in GDP growth rates, mainly due to World Wars $I$ and II. Futher, variability in growth rates appears to increase during the first half of the century and to decrease in the second half. In the course of the century, countries appear to have switched positions in a ranking by level of real GDP per capita and especially countries in North-Western Europe display similarities in growth pattems. Van Dijk's analysis is descriptive and exploratory; he concludes that extending the Tinbergen heritage to analyses of the long run $\mathrm{dy}$ namic behaviour of economic variables still requires great research efforts in the areas of model building and forecasting, with important long nun policy implications.

The central problem in labour market policies and incomes policies is bow to improve the plight of groups with low income, low earnings and low labour market attachment. Richard Bundell contributes an evaluative analysis of the effectiveness of policy reforms in this area. He explains how various policy instruments are targeted at different groups, and how they affect the often conflicting policy targets on income levels, labour market participation and budgetary costs. He discusses evidence on the effects of several elements of policy design, such as duration, eligibility and job search assistance. There are now many well developed techniques to evaluate alternative policies with data from designed on natural experiments. Yel, while Blundell draws on a rich list of evaluative studies, he conchdes that there remains much we need to know.

T.N. Srinivasan and Jessica Seddon Wallack examine the manifold relationships between globalization, economic growth, inequality and poverty from theoretical and empirical angles. They argue that opening up to trade and investment can contribute to each of the sources of economic growth: growth in inputs, more efficient use of resources and innovation. But, as empirical evidence bears out, these effects can vary as a result of different country characteristics. Through its effects on growth, globalization tends to contribute indirectly to poverty reduction, but there is also a direct effect. All in all, the authors conclude that the positive impact of globalization on poverty reduction is very likely to be stronger than that of redistributive policies. 
The editors of this special issue are indebted to the organizers of the conference: 'On the Wealth of Nations, Extending the Timbergen Heritage' where the majority of the articles of this issue were presented in slightly different form. Tinbergen bimself has always been acutely aware of the fact that none of his contributions could be considered final and that they should at best be seen as steps on the way to a better understanding of sociomeconomic phenomena and processes. The articles in this issue provide an illustration, describing some of the progress economic science has made since Tinbergen, in many cases on the basis of his publications. As Panl Samuelson writes in this issue: "That is science's way.'

Perer Comelisse, Herman van Dijk and Henk Don

\section{A BRIEF SURVEY OF TINBERGEN'S PROFESSIONAL LYE}

September 1921, starts study of Physics in Leiden

$1924-1926$, private study of Matbematical Economics and Statistics

July 1925, graduates in Physics

May 1926 - August 1927, works as conscientious objector in the Rotterdam peniientiary

August 1927 - May 1928, works as conscientious objector at the Dutch Central Bureau of Statistics

March 1929, obtains PhD degree at Leiden (Tite of dissertation: Minimum Problems in Physics and Economics (in Dutch)

$1929-1945$, works at the Central Bureau of Statistics

$1936-1938$, works at the League of Nations, Geneva on the project of "Statistical Testing of Business Cycle Theories'

1945 - 1955, Director of the Dutch Central Planning Bureau

1933 - 1956, Part-time professor at the Netheriands School of Economics, precursor of the present-day Erasmus University Rotterdam

1956 - 1973, Full-time professor at the Netherlands School of Economics. During this period Tinbergen also acted as advisor to the governments of many developing countries, such as Egypt, Turkey, Venezuela, Surinam, Indonesia and Pakistan and to international organizations as the European Coal and Steel Community, the United Nations and the International Bank for Reconstruction and Development.

1965, Chairman United Nations Committee for Development Planning

1 The comference was part of the Tinbergen week, from 7 to 11 April 2003 , organized by the Erasmus University Rotterdam on the occasion of Jan Tinbergen's $100^{\text {th }}$ birthday. 
1967, Praemium Erasmianum

1969, Nobel Prize in Economics (with Ragnar Frisch)

1973 - 1975, Cleveringa Chair at the University of Leiden

1992, Four Freedoms Award

June 9, 1994, deceased 
